\title{
暑熱環境下における至適速度でのジョギングが尿酸動態に及ぼす影響
}

\author{
木村直人, 伊藤孝 \\ 日本体育大学 衛生学公衆衛生学教室
}

\section{Effect of Optimum Jogging in a Hot Environment on Uric Acid Metabolism}

\author{
Naoto KIMURA and Takashi ITO \\ Department of Preventive Medicine and Public Health Nippon Sport Science University, Tokyo
}

\begin{abstract}
Objectives: The purpose of this study was to estimate the effect of optimum jogging in a hot environment on uric acid metabolism.

Methods: Six male subjects performed jogging at each optimum speed. The distance of jogging was $8000 \mathrm{~m}$ (400 $\mathrm{m}$ track $\times 20$ laps). Each jogging was performed twice, once in the summer season (Sept.) and once in the winter season (March). Blood samples were collected before and at $0,1,2,3,5$ and $24 \mathrm{~h}$ after each jogging. Urine was also collected before (after $60 \mathrm{~min}$ at rest) and from the onset of jogging until $24 \mathrm{~h}$ after.

Results: The wet bulb globe temperature (W.B.G.T.) during jogging ranged from 24.9 to $27.8^{\circ} \mathrm{C}$ in the summer and from 5.9 to $11.4^{\circ} \mathrm{C}$ in the winter. There was no difference in the duration of each jogging between summer and winter. However, the heart rate (H.R.) during jogging in the summer was higher than that in the winter. Serum uric acid at each rest ranged from, on average, 6.2 to 6.4 (mg/dl). After jogging in the summer, serum uric acid rose significantly $(p<0.05)$ and the increase was maintained until $5 \mathrm{~h}$ after. Exercise-induced hyperuricemia (above $7.5 \mathrm{mg} / \mathrm{dl}$ of serum uric acid) was shown in 3 out of all the subjects. In contrast, serum uric acid in the winter showed no significant change throughout protocol. There was no difference in the change in clearance of uric acid during each protocol between summer and winter. Urinary uric acid excretion at $24 \mathrm{~h}$ after, between summer and winter, showed similar levels. The rate of urinary oxypurine excretion (xanthine + hypoxanthine) in summer was higher than that in winter at $1 \mathrm{~h}$ and $\mathbf{2 h}$.

Conclusions: These results suggest that not only jogging but also a hot environment affects uric acid metabolism, especially the increase of purine nucleotide degradation.
\end{abstract}

Key words: uric acid metabolism（尿酸代謝）, hot environment（高温環境）, optimum jogging（至適速度でのジョギング）, purine nucleotide degradation（プリン・ヌクレオチド分解）

\section{緒言}

今日，身体活動や運動が及ぼす健康の保持・増進に対 する効果が知られるようになり，日常的に身体運動を実 施する人が数多く見られるよらになった。特に，特別の 施設を必要とせず，手軽に行らことができるジョギング は老若男女を問わず四季を通じて幅広く実施されてい る。しかしながら, ジョギングといっても, 各個人の強

受付 2003 年 8 月 1 日, 受理 2003 年 11 月 28 日

Reprint requests to: Naoto KIMURA

Department of Preventive Medicine and Public Health Nippon Sport Science University, 7-1-1 Fukasawa, Setagaya, Tokyo 158-8508, Japan TEL \& FAX: +81(3)5706-0970

E-mail: kimura@nittai.ac.jp
度（速度）は様々であり，さらに外的要因（季節差によ る環境条件等）の違いによっても生体に加わる負担も大 きく異なることが予想される。

一方, 身体運動後に血清尿酸値は一過性に上昇するこ とが知られており, この現象は運動性高尿酸現象と呼ば れている。特に, 激しい運動では翌日になっても運動前 の安静時までに回復しない高尿酸状態の持続化・恒久化 が，高尿酸血症や痛風などの疾病や，さらには急性の関 節炎や腎障害など多彩な疾患を高率に合併する危険性も ある $(1,2)$ 。著者ら $(3,4)$ は競技力の向上を図るための 強化合宿後や長期間の試合期間後において, 運動選手の 血清尿酸值が上昇し, 正常とされる上限值 $(7.5 \mathrm{mg} / \mathrm{dl})$ を 上回っていたことを報告した。しかしながら，健康の保 持・増進を目的とした各個人の至適レベルでのジョギン 
グが生体に及活す影響，特に血清尿酸值に及ぼす影響に ついてはあまり知られていない。ジョギングは年間を通 して実施されているため, 例兄ば夏季と冬季といった温 熱条件の違いによっても生体に及ぼす影響は異なる。特 に夏季に㧊ける暑熱環境下でのジョギングは，著しい体 温の上昇や発汗の増大をもたらすため, 活動筋も含めた 生体への負担は冬季に比べてょり高くなる (5)。その結 果, 筋原性由来による血清尿酸值の上昇に加えて, 脱水 などに伴う腎機能の低下から生じる尿中への尿酸排泄の 抑制が高尿酸化の持続をもたらすと思われる。したがっ て, 様々な季節, 特に生体への負担が高まる暑熱環境下 に怙ける至適速度でのジョギングが尿酸動態に及ぼす影 響を明らかにすることは，各個人の適正なトレーニング 処方や健康管理の観点からも大变意義のあることであ る。

本研究では, 健康管理の観点から, 夏季及び冬季にお ける各個人の至適速度でのジョギングが, 血中（血清） 尿酸及び尿中への尿酸排泄と言った尿酸動態に如何なる 影響を及ぼすかについて検討することを目的とした。

\section{方法}

\section{(1) 対象}

対象は年齢 $22 \sim 29$ 歳の健常男子 6 名（身長 $174.3 \pm 7.2$ $\mathrm{cm}$, 体重 $64.6 \pm 3.9 \mathrm{~kg}$ ) である。被検者には, 検査の実施 前に実験の目的及び方法について詳細に説明し同意を得 た。各被験者は, 過去において様々な運動（陸上競技, スキーなど）を行っていたものの，実験時においては， 少なくとも 1 年以上の定期的な運動習慣をもたない者で ある。

\section{(2) 運動プロトコール}

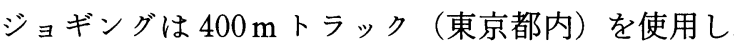
20 周（計 $8000 \mathrm{~m}$ ）を各個人の最も走りやすくかつ最後
まで走りきれる速度（至適速度）にて，それぞれ夏季 (9 月) 及び冬季 (3 月前半) の雨天時を除く日を選び, 数回に分けて（夏季： 2 回，冬季 3 回）実施した。ジョ ギングの開始時間はいずれも午前 9 時である。なお,

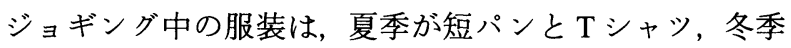
では長袖のトレーニングウェアにてそれぞれ実施した。 被検者 6 名のうち 3 名を選び心拍数の測定を行った。 ジョギング中の心拍数はHR モニター（ポーラ社製）を 用い, 1 分毎に記録した。さらにジョギング前後にそれ ぞれ体重を精密体重計（LDS- $150 \mathrm{H}( \pm 10 \mathrm{~g})$, 島津社製) を用いて測定した。ジョギング中の乾球温, 湿球温及び 黒球温は, $400 \mathrm{~m}$ トラックのコース上に設置された WBGT 計 (WBGT-101, 京都電子社製)を用いて1分毎に 記録しこれらの值から WBGT 温度を算出した (5)。

\section{(3) 採血及び採尿}

図 1 亿採血及び採尿の手順について示した。いずれの 実験も, 当日被検者には, 食事・水分等の摂取はさせ ず，できるだけ安静を保たせ来室させた。その後直ちに 排尿させ， 60 分間の座位安静の後に，採尿及び採血を 行った（Rest）。そして完全排尿をさせた後，それぞれ のジョギングを行った。ジョギング後の採血は, 直後か ら $1(1 \mathrm{~h}), 2(2 \mathrm{~h}), 3(3 \mathrm{~h}), 5(5 \mathrm{~h})$ 時間後及び翌朝の 空腹安静時（Rest2）とし，それぞれ肘正中皮静脈より 10 $\mathrm{ml}$ を採取した。採尿はジョギング直後から 5 時間後まで の 1 時間ごとと翌朝の安静 60 分間を検尿カップにて, ま た, 5 時間後以降から翌朝の安静 60 分間の尿を除いた 24 時間後までの尿は, 畜尿器（住友べークライト社製）を 用いてそれぞれ採取した。ジョギング直後から各時間毎 及び畜尿器に採取した尿の総量をもって 24 時間尿とし た。また，ジョギングなどの運動を 2 日間以上実施しな かった後の 24 時間尿（C）も併せて採取した。

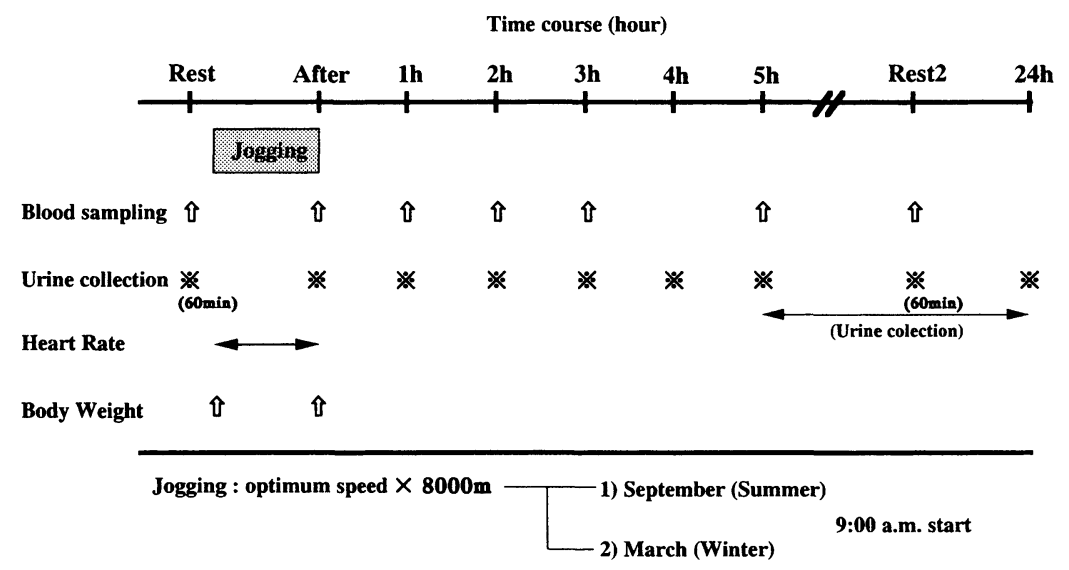

Fig. 1 The experimental protocol. 


\section{(4) 測定項目}

採取した血液は血中アンモニア（NH3），血中乳酸及び 尿酸の分析に供した。血中乳酸の測定は，採血後の血液 $0.5 \mathrm{ml}$ に氷冷してある $0.6 \mathrm{~N}$ 過塩素酸 $1 \mathrm{ml}$ を加えて除タン パクを行い，遠心分離後その上清を検体とし，酵素法 (ベーリンガーマンハイム社製) にて比色定量を行った。 血中 NH3 の測定は, 全血 $20 \mu \mathrm{ml}$ を専用の毛細管に採取し 試験紙上に分注した。その後, アミチェックメーター AA-4120（京都第一科学社製）にて定量を行った。血清 尿酸の測定は室温に $15 〜 20$ 分間放置した血液を，3000 $\mathrm{rpm}$ で 10 分間の遠心分離を行い血清を得た。そして血清 及び尿中尿酸を uricase peroxidaes 法（協和メディクス社 製）で，また尿中 oxypurines（hypoxanthine+xanthine）は xanthine oxidase peroxidase 法（協和メディクス社製）にて 分光光度計 (UV-160, 島津社製) を用いて分析を行っ た。得られた值から，単位時間あたりの尿中への尿酸排 泄の効率を示す尿酸クリアランス (CUA)を中村ら $(6,7)$ の方法を用い，以下の式にて算出した。

$$
\begin{aligned}
\text { 尿酸クリアランス }(\mathrm{CUA})= & \frac{(\text { 尿中尿酸濃度 }) \times(60 \text { 分間尿量 })}{(\text { 血中尿酸濃度 }) \times 60} \\
& \times \frac{1.48}{(\text { 体表面積 })}
\end{aligned}
$$

正常値 $9.4(6.2 \sim 12.6) \mathrm{ml} / \mathrm{min}$

\section{(5) 食事及び飲水について}

各実験の 2 日前より，被検者にはプリン体含有の少な い食物を摂取するように指示した。実験当日の食事につ いては, 1 回目の採血・採尿後に各自規定食を摂取させ, その後はジョギング終了 5 時間以降に食事（昼食（午後 $3 \sim 4$ 時）及び夕食（午後 $7 \sim 8$ 時)）を摂取させた。な 招, ジョギング終了 5 時間までの飲水は, ミネラルウオー ター $(\mathrm{Ca} ; 0.0024 \%, \mathrm{Na} ; 0.0081 \%, \mathrm{Mg} ; 0.0005 \%, \mathrm{~K}$; $0.00003 \% \mathrm{pH} 7.1$ ) あるいは打茶（ウーロン茶）とし，そ れ以降は自由とした。一方, アルコール摂取は血清尿酸 值を上昇させる $(8,9)$ ため, 各実験の前日及び終了する まで禁止とした。

\section{(6) 統計処理}

各項目の值は, 全て平均值士標準誤差 (mean \pm S.E.) で 示した。夏季及び冬季に打ける各パラメーターの変動は 共分散分析（ANOVA）を用いて検定を行った。そして, 有意差が得られた場合, Rest とジョギング後の值及び夏 季と冬季間との比較はそれぞれ Student t-test を用い，い ずれも5\%水準をもって有意とした。

\section{結果}

表 1 に夏季及び冬季における温熱条件, ジョギング時 間, ジョギング前後の体重及びジョギング後の飲水状況 についてそれぞれ示した。夏季の乾球温は $29 \sim 29.6^{\circ} \mathrm{C}$,
Table 1 The parameters of environmental condition, dura-

\begin{tabular}{|c|c|c|}
\hline & Summer (Sept.) & Winter (Mar.) \\
\hline Temp. $\left({ }^{\circ} \mathrm{C}\right)$ & $29.0 \sim 29.6$ & $7.0 \sim 15.0$ \\
\hline W.B.G.T. $\left({ }^{\circ} \mathrm{C}\right)$ & $24.9 \sim 27.8$ & $5.9 \sim 11.4$ \\
\hline Jogging period $(\mathrm{min})$ & $45.0 \pm 1.8$ & $44.7 \pm 1.6$ \\
\hline$\triangle$ body weight (kg) & $-1.30 \pm 0.01^{*}$ & $-0.66 \pm 0.09$ \\
\hline \multicolumn{3}{|l|}{ Water Intake (ml) } \\
\hline$\sim 5 \mathrm{~h}$ & $710 \pm 45.8$ & $428.0 \pm 44.5$ \\
\hline$\sim 24 \mathrm{~h}$ & $1864.0 \pm 198.8$ & $1222.0 \pm 198.4$ \\
\hline
\end{tabular}
tion, body weight and water intake in each protocol

${ }^{*} \mathrm{p}<0.05$ : Significant difference between summer and winter. W.B.G.T.: Wet Bulb Globe Temperature.

湿度 $46 \sim 69 \%$, また冬季では乾球温は $7.0 \sim 15.0^{\circ} \mathrm{C}$, 湿 度 $48 \sim 71 \%$ であった。WBGT ではそれぞれ $24.9 \sim 27.8^{\circ} \mathrm{C}$ (夏季) 及び $5.9 \sim 11.4^{\circ} \mathrm{C}$ (冬季) の範囲であった。ジョ ギング時間は両時期において違いは見られなかった。 ジョギング前後における体重の変化では, 冬季 $(-0.7 \mathrm{~kg})$ に比べて夏季 $(-1.3 \mathrm{~kg})$ に著しい減少 $(\mathrm{p}<0.05)$ が認め られた。また，ジョギング後の飲水状況においても，冬 季に比べて夏季の方が多い飲水量を示していた。

図 2 には被検者 3 名に拈けるジョギング中の心拍数の 変化を 5 分毎に示した。両季節ともジョギングの開始と 共に心拍数は上昇を示した。しかしながら，その程度は 異なって打り, 冬季（平均 $146 〜 167$ 拍 / 分）に比べ夏 季 (平均 $152 \sim 183$ 拍 / 分) の心拍数がジョギング中を 通して有意に高い值（p<0.05）を維持していた。

図 3 に血中乳酸及びNH3 の変化についてそれぞれ示し た。両季節ともジョギング終了直後に有意な上昇 $(\mathrm{p}<0.05)$ を示していた。しかしながら，両季節においてその程度 は異なり, 血中乳酸及び NH3 とも冬季に比べて夏季にお いて高値を示しており，NH3 においては夏季及び冬季間 において有意差 $(\mathrm{p}<0.05)$ が認められた。しかしながら, 両項目とも $1 \mathrm{~h}$ 以降は低下を示し, $2 \mathrm{~h}$ 後には安静時の値

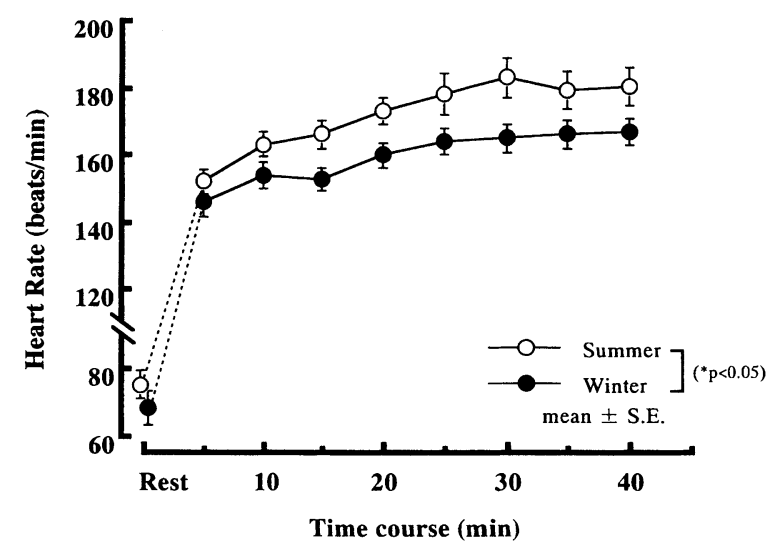

Fig. 2 Changes in average heart rate (H.R.) during optimum jogging in the summer and winter.

${ }^{*} p<0.05$ :significant difference between summer and winter. 

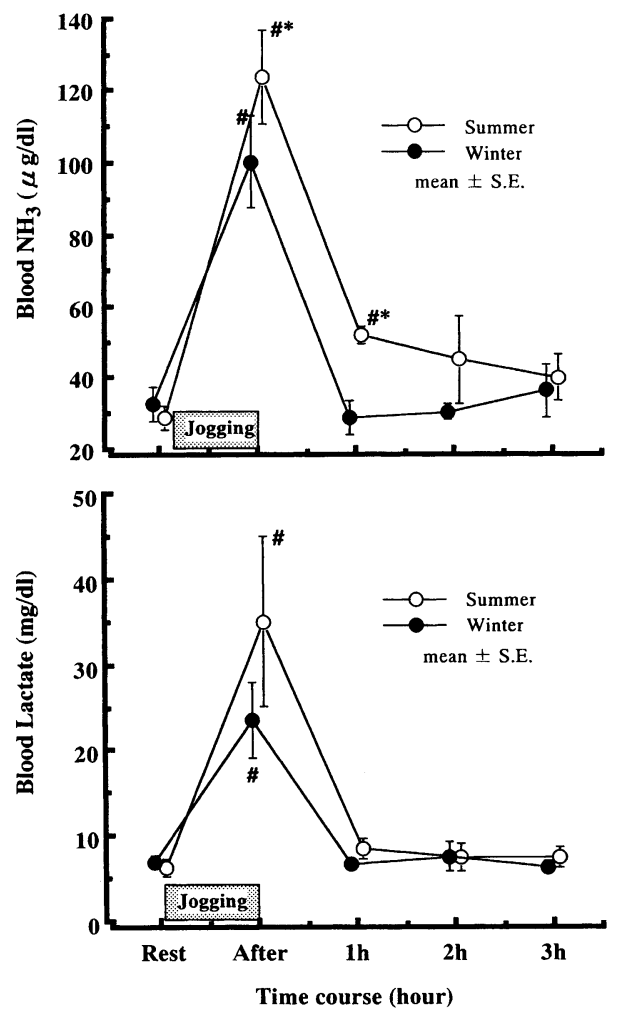

Fig. 3 Changes in blood lactate and ammonia (NH3) during each protocol.

${ }^{*} p<0.05$ :significant difference between summer and winter. $\# \mathbf{p}<0.05$ :significant difference from each rest.

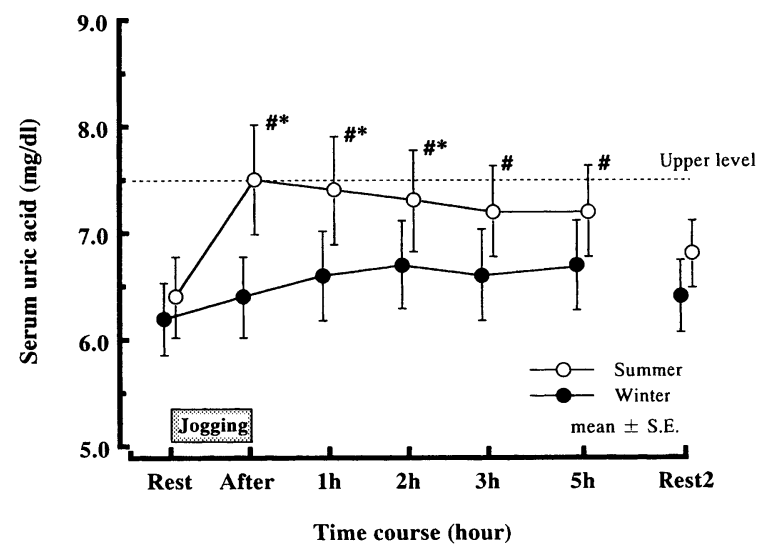

Fig. 4 Change in serum uric acid during each protocol. * $p<0.05$ :significant difference between summer and winter. $\# p<0.05$ :significant difference from each rest.

\section{に回復していた。}

図 4 に両季節における血清尿酸值の変化を示した。安 静時の値は平均 $6.2 \sim 6.4 \mathrm{mg} / \mathrm{dl}$ であった。ジョギング後 において, 夏季の血清尿酸值は上昇し, $7.5 \pm 0.5 \mathrm{mg} / \mathrm{dl}$ と 最高值を示していた。特に正常域の上限である $7.5 \mathrm{mg} / \mathrm{dl}$ を上回った者が 6 名中 3 名認められた。さらにそれ以降 は僅かな減少傾向がみられるものの, $5 \mathrm{~h}$ 後まで有意な高

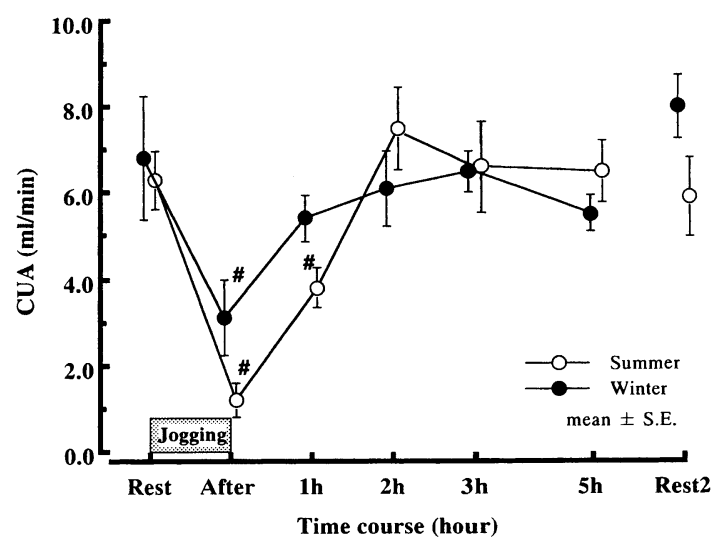

Fig. 5 Change in clearance of uric acid (CUA) during each protocol.

\# $\mathbf{p}<0.05$ :significant difference from each rest.

値（p<0.05）を示し, 翌日の安静時（Rest2）においても 平均 $6.8 \pm 0.3 \mathrm{mg} / \mathrm{dl}$ と, 負荷前値までの回復に至らなかっ た。一方，冬季では，負荷後に僅かな上昇は見られたも のの，その後低下し翌日（Rest2）では負荷前と同程度の 値を示していた。

図 5 には両季節に打ける尿酸クリアランス（CUA）の 変動を示した。いずれの季節とも安静時に比べジョギン グ直後に有意な低下（p<0.05）を示していた。特に負荷 直後及び $1 \mathrm{~h}$ 後の夏季の低下の程度は冬季に比べて著明 であった。その後は上昇し, 特に夏季の $2 \mathrm{~h}$ 後では安静 時レベルを上回って高值となり, $3 \mathrm{~h}$ 以後はいずれの時期 とも安静時レベルに回復していた。しかしながら，両季 節間において統計的な違いは認められなかった。

図 6 にはジョギング直後からの 24 時間の尿中尿酸排 泄量を示した。24 時間の尿中尿酸排泄量は両季節に打い て違いは認められなかった（夏季 : $654.8 \pm 43.1 \mathrm{mg} / \mathrm{day}$, 冬季 : $674.8 \pm 70.6 \mathrm{mg} / \mathrm{day}) 。$ また これらの值は両季節で の運動を実施していない 1 日（C）のそれらとも同程度

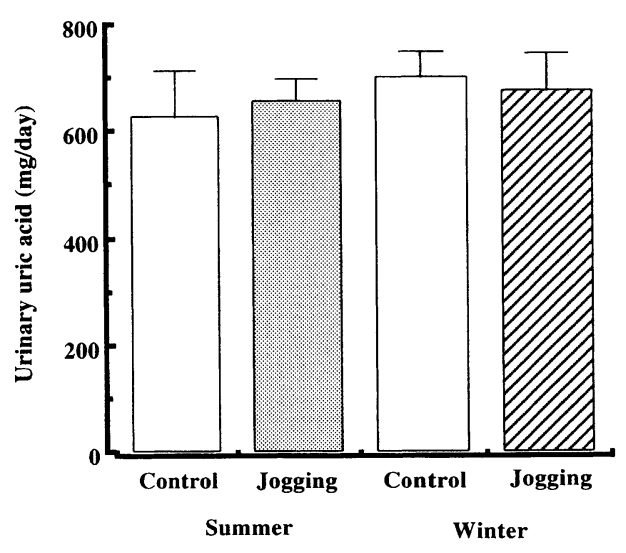

Fig. 6 Change in urinary uric acid (mg/day) during each protocol (jogging and control). 
であった。

図 7 に夏季及び冬季の単位時間当たりの尿中 oxypurines 排泄量 $(\mu \mathrm{g} / \mathrm{min})$ の変化を示した。ジョギング直後 に打いて低下を示したものの, 両季節とも $1 \mathrm{~h}$ 後には上 昇し最高值となった（ $\mathrm{p}<0.05 ） 。$ 特に，夏季における尿 中 oxypurines 排泄量は冬季のそれに比べて高い傾向を示 していた。その後，尿中 oxypurines 排泄量は減少を示し， $3 \mathrm{~h}$ 後には安静時レベルに回復（低下）していた。一方， 24 時間の尿中 oxypurines 排泄量として見ると, 冬季 $(20.3$ $\pm 1.7 \mathrm{mg} / 24 \mathrm{~h})$ に比べ夏季 $(23.7 \pm 3.0 \mathrm{mg} / 24 \mathrm{~h})$ において高 い傾向を示していた。

\section{考察}

運動の実施に伴い一過性に血清尿酸値が上昇する運動 性高尿酸現象が，健康の保持・増進を目的とした各個人 の至適レベルでのジョギングに沶いても見られ，特に夏 季において著明であった。

運動性高尿酸現象の発生機序については, 尿酸の過剰 産生（筇原性機序）と腎からの排泄低下（腎性機序）の いずれか，またはその両者の混合とに起因するとされて いる $(1,2,10)$ 。筋に拈ける尿酸の過唾産生 (筋原性機序) に関して, Sutton, J.R. ら（10）は運動中に筋の purine nucleotide 分解の高まることがその原因の一つであると述 べている。運動中, 筋収縮に必要とされるエネルギー消 費が著しく増大した場合, ATP/ADP 比やアデニル酸エネ ルギーチャージ（ATP+0.5ADP/ATP+ADP+AMP）等が低 下を示す。筋においては，このエネルギー代謝の効率を 保持する観点から, NH3 の産生を伴って AMPの脱アミノ 化が生じ細胞膜の通過しにくいIMP として保持される。 そして，運動後に再び合成され， adenine nucleotide pool へ返還されるものの, その一部は細胞膜の通過しやすい inosine や hypoxanthine まで分解し血中へと放出される。さ らに肝蔵において xanthine oxidase の働きにより尿酸への

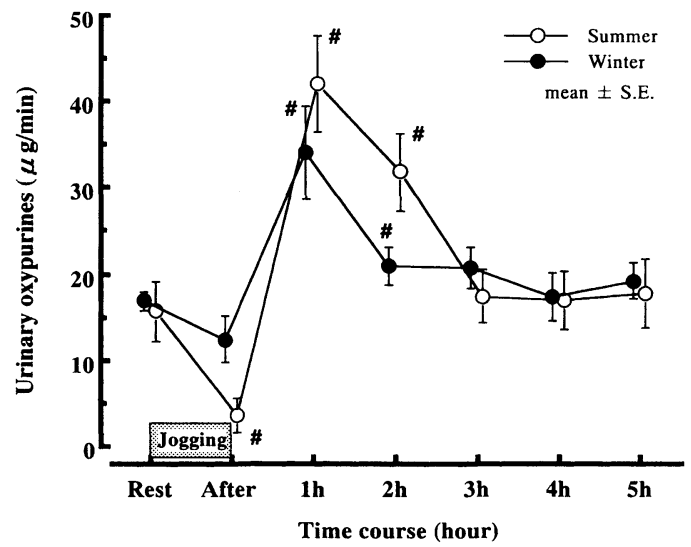

Fig. 7 Change in urinary oxypurines (xanthine + hypoxanthine) during each protocol.

$\# p<0.05$ :significant difference from each rest.
合成が高まり，高尿酸現象が発現する $(1,10)$ 。本研究に おいて, AMP の脱アミノ化に伴って生じる NH3 の産生 は夏季に括いて有意に高く（p<0.05），さらには尿酸生 成の先駆物質である尿中 oxypurines の排泄動態 $(1 \mathrm{~h}$ 及び $2 \mathrm{~h}$ の排泄率）も, 冬季に比べ夏季に拈いて高い傾向を示 していた。本研究ではアロプリノール等の尿酸生成抑制 剂を投与していないため，尿中 oxypurines を最終代謝産 物とし，尿酸生成量の指標として定量的な評価をするこ とはできないものの, これらの結果から, 中程度の強度 と思われる至適速度でのジョギングであっても，夏季に おいてはAMPの脱アミノ化に伴う purine nucleotide の分 解は六進していたことになる。先行研究において purine nucleotide の分解には負荷強度の上昇 $\left(60 \% \dot{\mathrm{VO}}_{2} \max\right.$ 以上) や過度な運動量（疲労困䣏に至るまでの $2 / 3$ 以上の運動 量）によって元進することが知られている $(11,12)$ 。し かしながら, 本研究の結果から, 強度や運動量といった 運動条件のみならず外部環境（暑熱環境）もまた purine nucleotide 分解に関与することが示唆された。

暑熱環境下における運動は, 骨格筋における熱の産生 と外部からの暑熱環境が加わる。その時, 体内における 産熱量が放熱量を上回るため，体温は著しく上昇する。 そして，その継続は運動能力の低下につながり，結果と して，熱中症を発症する原因と考えられている $(5,13)$ 。 スポーツ活動時に打ける熱中症発生について検討した先 行研究を見ると, 運動種目では野球が最も多く，またラ ンニング時での発生が多いことことも報告されている (14)。一方，学校管理下における体育・スポーツ活動時 の事例として，夏季に打ける死亡事例では，約 $48 \%$ がラ ンニング実施中に発生していた（15）。また，ランニング などの屋外種目のみならず剣道, フェンシングと言った 屋内種目の事例も報告されており, 全身を覆らユニ フォームが運動中の熱放散を阻害することが要因とされ ている $(16,17)$ 。

本研究において，夏季におけるジョギング中の環境温 度（WBGT）は, $24.9 \sim 27.8^{\circ} \mathrm{C}$ であり, 熱中症予防のガ イドラインでは，「警戒（積極的に休息）」の区分にあっ た (5)。また, 着衣条件も短パン・Tシャツ等の薄着で あった。暑熱環境下におけるジョギングが笳内における purine nucleotideの分解を六進するメカニズムは明らかで ないが, 夏季のジョギング中に見られる漸増的な心拍数 の上昇や体重の約 $2 \%$ 程度の脱水から, 先に示した皮膚 血流量の増大に伴ら循環血液量の低下 $(18,19)$ や,さら に脱水に伴う血液粘性の増大などが生じたため, 夏季に おけるジョギング中の血液の循環効率は低下していたと 予想される。そのため，暑熱環境下においては，筋への 血流に伴う酸素運搬能に制限が生じたかもしれない。こ の酸素運搬能の制限はジョギング中における筋での有酸 素的なエネルギ一供給やその効率等を制限し，代償的に 解糖系などの無酸素的なエネルギ一供給を六進させる。 本研究においてもジョギング後に打ける乳酸上昇の程度 は，冬季に比べ夏季に打いて高い傾向にあった。血中の 
乳酸レベルが著しく上昇を開始する無酸素性作業閾值 (Anaerobic Threshold; AT) を上回る運動の実施は，血中 oxypurines や血清尿酸值を上昇させることが知られてい る (12)。本研究では，各個人の ATレベルの測定を行っ ていないものの，上述した結果と先行研究から，夏季に 扣ける至的速度でのジョギングの場合，ジョギングとし ての強度は中程度であったとしても，夏季に拈いては暑 熱環境の影響も生体に大きく加わるため, 例えばATレ ベルを上回るよらな強度に至ったと思われる。そして, このことが夏季におけるジョギング中の purine nucleotideの分解（NH3 の上昇）をより亩進させた理由の一つ であろら。したがって，運動（ジョギング）は直接筋内 における purine nucleotide の分解に関与するものの, 暑熱 環境はそれらの分解の六進を間接的に促進すると推察し た。

一方，腎からの排泄低下（腎性機序）に関しては，運 動後に見られる乳酸の蓄積や腎血流量の低下などにより 腎からの尿酸排泄を抑制することが知られている $(20,21)$ 。本研究において, 夏季及び冬季における乳酸值 はジョギング直後に打いて上昇を示した。またCUAに おいてはジョギング直後に最も低值となった。これらの 結果から, 両季節とも乳酸の上昇に伴ら代謝性アシドー シスや腎血流量の低下による影響が一時的に高まったも のと思われる。しかしながら，その後は逆に上昇し $2 \mathrm{~h} に$ は安静時レベルに回復していた。また，実験全体を通し て CUA や 24 時間の尿中尿酸排泄量には，夏季及び冬季 間に統計的な差異は見られなかった。一方，本実験では ジョギング直後から $5 \mathrm{~h}$ 後までの水分摂取を，尿酸排泄 に影響が少ないミネラルウオーターあるいは搽（ウー ロン茶）であった。著者ら（22）は，その後の実験におい て運動後の尿酸排泄に関与する水分摂取の質及び量につ いて検討した。その結果，尿中への尿酸排泄を促すため には摄取する水分の量よりも質, 特にナトリウムやカリ ウムなどの電解質の重要性について報告している。本研 究で用いた $5 \mathrm{~h}$ 後までの水分補給では，ナトリウムやカ リウム等の電解質が皃とんど含まれていないため，夏季 の飲水量は冬季の約 1.5 倍であったにもかかわらず，尿 中への効果的な尿酸排泄が得られないと思われる。そし て，このことが両時期の尿酸排泄に差異をもたらさな かった理由の一つであろら。また，24時間の尿中尿酸排 泄量はいずれの季節とも運動を実施していない時と同程 度のレベルであった。これらの結果は, 腎からの尿酸排 泄に対して中程度レベルのジョギングや暑熱環境が著し く影響（尿酸排泄の制限）を及ぼさないことを示唆して いる。本研究の結果から, 至適速度でのジョギングによ り腎性機序の一時的な低下がそれぞれ見られるものの, その後の尿中への尿酸排泄の制限が長時間にわたって見 られなかったことから，尿酸排泄の制限が夏季における 高尿酸現象を生じさせた要因とは考えがたい。

以上の結果から，各個人に拈いて至適速度でのジョギ ングであっても, 環境条件の違いにより purine nucleotide
分解の程度や高尿酸現象の発現の有無も異なっていた。 特に，暑熱環境下においては，運動による影響のみなら ず，暑熱条件も相乗的に purine nucleotide 分解の元進を促 すため，高尿酸現象をより発症し易くするものと思われ る。暑熱条件下における運動の実施により purine nucleotide 分解の亢進やさらには高尿酸現象が発生する事はさ けがたいと思われる。それに対して，それに見合っただ けの尿酸排泄が運動後に得られれば，高尿酸状態の持続 を防止することが可能となる。さらに，暑熱環境下にお いては発汗による体水分の損失も大きくなるため，体液 のバランスの早い回復を計る観点からも，運動後の水分 補給を考慮することが必要となる。したがって，暑熱環 境下でのスポーツ場面では，各個人の健康管理，すなわ ち高尿酸状態の改善と暑熱障害の予防，すなわち脱水か らの体液バランスをより早く回復させる観点から, ジョ ギング後の水分や塩分（ナトリウムなど）などの電解質 の補給のみならず，併せて $3 \sim 5 \%$ の糖分を搷ることや， ある程度冷やす $\left(5 \sim 15^{\circ} \mathrm{C}\right)$ ことなどが，より効果的な 手段と思われる (5)。さらに，運動後，ストレッチング などの軽運動の実施なども尿酸排泄に有効であると報告 されていることから (23), 筋疲労の回復の観点からも, ジョギング後のケアの実施がこれらの障害予防を計るら えで重要であることが示唆された。

\section{要 約}

本研究では，健康管理の観点から，夏季及び冬季にお ける各個人の至適速度でのジョギングが尿酸動態に如何 なる影響を及ぼすかについて，血中（血清尿酸）及び尿 中への尿酸排泄動態を明らかにすることを目的とした。

主な結果は以下の通りである。

1）血中乳酸及び NH3 は両季節ともジョギング終了值 後に有意な上昇（p<0.05）を示しており，特に夏季 の上昇が冬季の值に比べて高く，血中 NH3 に打いて は有意差（p<0.05）が認められた。

2）ジョギング後において, 夏季の血清尿酸值は上昇し, 直後 $7.5 \pm 0.5 \mathrm{mg} / \mathrm{dl}$ と最高值となった。特に正常域 $(7.5 \mathrm{mg} / \mathrm{dl}$ 以上) を上回るものが 6 名中 3 名認められ た。さらに，それ以降は減少傾向がみられるものの $5 \mathrm{~h}$ 後まで有意な高值 $(\mathrm{p}<0.05)$ を示し, 翌日の安静 時（Rest2）に扎いてもジョギング前值までの回復に は至らなかった。一方, 冬季の血清尿酸值では, ショョ ギング後に僅かな変動（上昇）は見られたものの， 翌日には低下しジョギング前と同程度の值を示して いた。

3）両季節における康酸クリアランス（CUA）は，いず れもジョギング直後及び $1 \mathrm{~h}$ 後に有意な低下 $(\mathrm{p}<0.05)$ を示していた。しかしながら，その後は上昇し， $3 \mathrm{~h}$ 後には安静時レベルに回復していた。両季節間にお いてその変化に統計的な違いは認められなかった。 また， 24 時間の尿中尿酸排泄量は両季節間において 
違いが見られず，またこの値は両季節での運動を実 施していない 1 日の尿酸排泄量と同レベルであっ た。

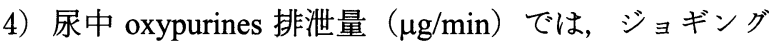
$1 \mathrm{~h}$ 及び $2 \mathrm{~h}$ 後において夏季の排泄量が冬季のそれを 上回っていたものの, $3 \mathrm{~h}$ 後には安静時レベルに回復 （低下）していた。

以上の結果から, 健康の保持・増進を目的とした至適 速度でのジョギングでも，季節（環境温度等）の違いに よってその変動は異なっていた。特に暑熱環境下におけ るジョギングの実施は, 著しく血清尿酸值を上昇させる。 この要因として, 血中 NH3 や尿中 oxypurines 排泄量の増 大などに見られる骨格笳に打ける尿酸産生の六進 (purine nucleotide 分解) が原因と思われる。したがって, 運動のみならず暑熱環境も尿酸産生を相乗的に妄進させ る要因であることが示唆された。

\section{文献}

（1）橋詰直孝, 松本貴之. 高尿酸血症 - 低尿酸血症一痛風 の治療新ガイドライン一 運動の影響 日本臨床 2003; 61 (増刊号 1) : 138-142.

（2）藤森 新. 高尿酸血症・低尿酸血症一痛風の治療新ガ イドラインー 高尿酸血症の定義と病因別分類 日 本臨床 $2003 ; 61$ (増刊号 1) : 161-165.

（3）伊藤 孝, 木村直人, 松井徳美, 西川槇八. 大学女子 フェンシング選手の合宿に抢ける血中乳酸, 血清尿酸 並びに尿中 17-OHCS の動態に関する研究 日本体育 大学紀要 1987; 16(2): 137-144.

（4）木村直人，伊藤 孝. 運動選手の尿酸動態に関する研 究 日本体育大学紀要 $1991 ; 20(2): 123-128$.

（5）川原 貴, 森本武利編. スポーツ活動中の熱中症予防 ガイドブック 日本体育協会編 (1994)

（6）中村 徹，田中経雄. 尿酸動態検索法としての尿酸》 リアランス試験 日本臨床 1991；49(5): 15-24.

（7）中村 徹, 田中経雄. 尿酸の排泄 臨床検査 1993; 37 : 247-251.

(8) Lieber CS, Jones DP, Losowsky MS, Davidson C. Interrelation of uric acid and ethanol metabolism in man. J Clin Invest $1962 ; 41(10): 1863-1870$.

（9）山本徹也. 高尿酸血症 - 低尿酸血症一痛風の治療新ガ イドラインー アルコールの影響日本臨床 2003;
61（増刊号 1)：143-147.

(10) Sutton JR. Purine metabolism during strenuous musclar exercise in man Metabolism 1980; 29: 254-260.

（11）木村直人，深澤 健，高西俊正，津田博子，伊藤 孝. 重量負荷時における尿酸動態に関する研究一高強度 負荷に打ける実施回数の相違について一 体力・栄 養・免疫学雑誌 1999; 9(1): 21-29.

(12) Yamanaka H, Kawagoe Y, Taniguchi A, Kaneko N, Kimata S, Hosoda S, Kamatani N, Kashiwazaki S. Accelerated purine nucleotide degradation by anaerobic but not by aerobic ergometer muscle exercise. Metabolism 1992; 41: 364369.

（13）平田耕造, 井上芳光, 近藤徳彦. 体温一運動時の体温 調節システムとそれを修飾する要因一 東京 有限 会社ナップ 2002 .

（14）中井誠一，寄本明，森本武利. 環境温度と運動時熱中 症事故発生との関係 体力科学 1992； 41: 540-547.

（15）星 秋夫, 稲葉 裕. 学校での運動時における外因性 死亡の発生状況 体力科学 2002; 51: 85-92.

（16）中井誠一、アメリカンフットボールの暑さ対策 臨床 スポーツ医学 1997; 14(7): 763-768.

（17）新矢博美，芳田哲也，高橋英一，常岡秀行，中井誠一. 高温下運動時の体温調節反応に及ぼすフェンシング ユニフォームの影響一現場調査及び実験室的検討一 体力科学 2003; 52 : 75-88.

(18) Brengelmann GL, Johnson JM, Hermansen L, Rowell LB. Altered control of skin blood flow during exercise at high internal temperature. J Appl Physiol 1977; 43(5) : 790794.

(19) Nose H, Takamata A, Mack GW, Oda Y, Kawabata T, Hashimoto S, Hirose M, Chihara E, Morimoto T.Right aerial pressure and forearm blood flow during prolonged exercise in a hot environment. Pfugers Arch 1994; 426: 177-182.

(20) Nichols, J. Influence of muscular exercise on uric acid excretion in man J.Appl.Physiol. 1950; 3: 501-507.

（21）細谷龍男, 田部 晃, 岡部英明, 佐治正勝. 尿酸排泄 低下の機序 高尿酸血症と痛風 1993; 1:27-32.

（22）高西敏正，木村直人，伊藤 孝，諸富嘉男，井谷 徹. 高強度・長時間運動による摂取水分の量及び組成の違 いが尿酸代謝に及ぼす影響 日本衛生学雑誌 1998; $53(2): 463-469$

（23）曲 剛健，伊藤 朗. 尿酸代謝（高尿酸血症，痛風） 各論（1） 臨床スポーツ医学 1995；12: 894-897. 